\title{
Predicted Speciation and Mineral Solid Phases of some Heavy Metals in Sludge - amended Soil \\ El-Gendi, S. A. ${ }^{\text {; }}$ A. I. El-Desoky ${ }^{2}$ and M. Y. Khalafalla ${ }^{2}$ \\ ${ }^{1}$ Soil, Water and Envi. Res. Inst., Agric. Res. Center, Giza, Egypt \\ ${ }^{2}$ Soils and Water Sci. Dept., Fac. of Agric., Al-Azhar Univ., Assuit, Egypt.
}

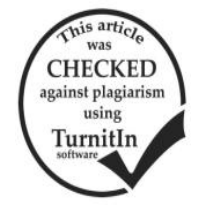

\section{ABSTRACT}

Speciation of heavy metals exerts important controls on chemical behavior, solubility, toxicity, adsorption and even physical properties of solutions (Ure and Davidson 2002). In the present study, speciation and mineral-solid phase of Cd, $\mathrm{Ni}$, and $\mathrm{Pb}$ in solution of soil prolonged irrigated with sewage effluent were predicted using GEOCHEM model (Sposito and Mattigod (1980) and constructed stability diagrams (Sposito ,1989 and Lindsay ,1979).The present data indicate that total contents of all tested metals have increased dramatically as a result of sludge amending, particularly, for $\mathrm{Cd}$. In virgin soil solution, the results of speciation indicated that, free species $\mathrm{M}^{2+}$ was the prevalent form $(60.35 \%)$ followed by carbonate species $\mathrm{MCO}_{3}$ aq $(20.12 \%), \mathrm{MSO}_{4}(5.93 \%), \mathrm{MHCO}_{3}^{+}(5.56 \%)$, $\mathrm{MOH}^{+}(4.21 \%)$ and $\mathrm{MCL}^{+}(4.21 \%)$, while in sludge - soil solution the sequence was; M-DOC (41.92\%), followed by $\mathrm{MHPO}_{4}$ species $(26.74 \%), \mathrm{M}^{2+}(20.07 \%), \mathrm{MHCO}^{+}(4.22 \%), \mathrm{MSO}_{4}$ aq $(3.49 \%)$ and $\mathrm{MCO}_{3}$ aq $(2.02 \%)$. It is clear from the results that amending soil with sludge decreases active portion $\left(\mathrm{M}^{+2}\right)$ contribution to total speciation of the tested metals. In virgin soil, the majority of both $\mathrm{Cd}$ and $\mathrm{Ni}$ was $\left(\mathrm{M}^{+2}\right)$ species. It amounted $(79.03 \%)$ and $(83.8 \%)$, respectively. While $\mathrm{MCO}_{3}$ aq was the prominent for pb $(55.86 \%)$. In sludgesoil, $\mathrm{Pb}$ was almost exclusively in organically complexed forms $(88.54 \%)$, while the majority species of $\mathrm{Ni}$ was $\mathrm{M}^{+2}(38.56 \%)$ and for $\mathrm{Cd}, \mathrm{CdHPO}_{4 \mathrm{aq}}(58.72 \%)$. The data also showed that in sludge- soil the activities $\left(\mathrm{Ml}^{-1}\right)$ of both $\mathrm{Pb}$ and $\mathrm{Ni}$ decreased by $26 \%$ and $72 \%$, respectively, compared to their corresponding values in virgin soil. Meanwhile, the activity of $\mathrm{Cd}$ increased. These findings suggesting that amending soil with sludge probably inhibit activities of some metals, while promote activity of others. The data showed that the values of activities of $\mathrm{Cd}$ in virgin soil was closed to the solubility of $\mathrm{CdCO}_{3}\left(\log \mathrm{CO}_{2}=-2.52\right)$ and $\mathrm{CdSO}_{4}-2 \mathrm{Cd}(\mathrm{OH})_{2}$ at $\left(\log \mathrm{So}_{4}=-2\right)$, while in sludge soil ,the value of $\mathrm{Cd}^{+2}$ was under saturated with respect the constructed $\mathrm{Cd}$ - minerals. This suggested that other possible solid phase of cadmium may be controlling its activity in that soil .Also, the data suggested that activity of $\mathrm{Ni}^{+2}$ in virgin soil is governed by $\mathrm{Ni}_{3}\left(\mathrm{PO}_{4}\right)_{2}$ in equilibrium by gypsite. While in sludge-soil, value of $\mathrm{Ni}^{+2}$ was controlled by $\mathrm{Ni}_{3}\left(\mathrm{PO}_{4}\right)_{2}$ in equilibrium with Caphosphate mineral at $\left(\log \mathrm{CO}_{2}=-4.52\right)$. Also, the results indicated that $\mathrm{Pb}_{3}\left(\mathrm{CO}_{3}\right)_{2}(\mathrm{OH})_{2}$ was the possible solid phase which may be controlled the activity of $\mathrm{Pb}^{+2}$, in both virgin and sludge soil.

Keywords; sewage effluent, heavy metals, speciation, stability diagrams

\section{INTRODUCTION}

Many farmers around the world are even compelled to use sewage effluent water to irrigate their crops, due to paucity of fresh water (absence of alternatives) .Despite thatwater contains high levels of organic materials and plant nutrients, and it also contains numerous pathogenic microorganisms, toxic compounds and heavy metals (metalloids). The majorities of heavy metals are toxic even at low concentrations and are capable of entering the food chain, where they accumulate and inflict damage to living organisms (Davis et al., 1992, Katbata-Pendias, 1993, Alloway, 1995).

It is generally recognized that the particular behavior of heavy metals in the environment isdetermined by their specific physicochemical forms rather than by their total concentration (Cances, et. al., 2003 and Yuan, 2009). In addition, Artiola (2005) and Beata, et. al. (2014) reported thatmetals exist in a number of different soluble and particulate forms (species), which influence their mobility and bio availability and free metal activity has been shown to be the key factor in determining metal bioavailability and toxicity in most circumstance (Parker and Pedler, 1996, Weng et al., 2001).

There are several methods for determination metal species in soil solution, each method has its advantages and limitations ((Florence, 1986, Apte and Batley, 1995, Mota and Correia dos Santos, 1995) and generally based on a more profound analytical back ground (e.g., $\mathrm{pH}$, concentration of competing ions, concentration of complexing ligands in solution, and the soil colloid) and characteristics of soil biota (Temminghoff et al., 2000). For instance, Ion selective electrode (ISE) method is simple and cheap and directly measure the free portion of metal in solution (Mota and Correia dos Santos, 1995). But its detection limit ishigh, and may also suffer from inter ferences. The voltammetric and polarography methods is a very sensitive, but the equilibrium of reaction is hardly achieved (Nordstrom, 1996).Competitive chelation could achieve free heavy metal ions concentrations directly with good sensitivity, while chelatesattain equilibrium with soils very slowly (Norvell and Lindsay, 1969, 1972, Workman and Lindsay, 1990). The cation exchange resin method is rapid and sensitive, but required some precautions about selected resin (Apte and Batley, 1995). This make the method complicated (Fotovat and Naidu, 1997). Donnan membrane technique able to measure several free metal ion concentrations at the same time, moreover, all the metals did not interfere each other (Temminghoff et al., 2000 and LI YI , et al., 2007). They added that attaining equilibrium under procedure circumstances was difficult, beside over estimated due to dissociation of labile species.

Soil solution speciation may be estimated using computer programs like GEOCHEM model (Sposito and Mattigod (1980), MINTEQ model (Allison et al.,1991 and Schecher and McAvoy ,2003) and ORCHESTRA model (Meeussen , 2003). From the computational side, limitations include the uncertainty about the most appropriate equilibrium constants and the measured input data, and the fact reaction kinetics are not considered (Thomas et. al., 2005).

Stability diagrams are used as a convenient technique for illustrating how the solubility of metal compounds varies with soil $\mathrm{pH}$ and with metal concentration (or activity). The diagrams also allow some prediction of which solid phase regulates metal activity in the soil solution (El-Falaky et. al., 1991, El-Gendi, 1994 , El-Gendi et al., 2017).

The objectives of this study are to estimate ion speciation of cadmium, Nickle and in sludge-amended soil solution using MINTEQ model (Allison et al., 1991 and 
Schecher and McAvoy, 2003) and predict mineral solid phases which may controlling activities ofthat metals using stability diagrams.

\section{MATERIALS AND METHODS}

\section{1-Site description and soil samples}

The studied soil samples selected from the agriculture farm of El-Gabal Al-Asfer Sewage station which located at $25 \mathrm{Km}$ north- east of Cairo. This farm has been irrigated with sewage for over 50 years and thereby, providesa possible model of the potential long-term effects of heavy metals on terrestrial ecosystem.

Two sites were selected for sampling the first site represents soils which continuously irrigated with sewage water over 50 years, while the second represent uncultivated area. At each site, five surface soil samples ( 0 $-30 \mathrm{~cm}$ ) were collected, air-dried, grounded, sieved, mixed to make two composite samples.

\section{2- Soil analysis}

The following analysis were carried on the samples;

1- Soil organic matter content was determined according to the method of modified Walkley and Black Method, Jackson (1984). Total calcium carbonate content (TCC) in soil was determined volumetrically using Collin's Calcimeter (Jackson 1984).Soil fraction analysis; was carried by pipette method according to Piper(1950).Electrical conductivity , $\mathrm{pH}$ and soluble ions were determined in the according to (Page et al.1982). Dissolved organic carbon (DOC) was extracted from $10 \mathrm{~g}$ fresh soil using $40 \mathrm{ml}$ distilled water according to method of Zsolnay (2003). The soil samples were shacken for $30 \mathrm{~min}$ at speed of $250 \mathrm{r} \mathrm{min}-1$, the supernatant was centrifuged for $10 \mathrm{~min}$ at $15,000 \mathrm{r}$ min-1 and filtered by $0.45 \mathrm{um}$ cellulose ester filters. The extracts were analyzed for $\mathrm{C}$ using TOC analyzer. DOC was determined by wet Oxidation which carried out according to the method proposed by Moore (1985). A sample of $25 \mathrm{ml}$ DOC extract was evaporated to drynessat $90^{\circ} \mathrm{C}$, and then digested in a boiling water bath for $3 \mathrm{~h}$ with $25 \mathrm{ml}$ of concentrated $\mathrm{H}_{2} \mathrm{SO}_{4} / \mathrm{H}_{3} \mathrm{PO}_{4}(2: 1$ $\mathrm{v} / \mathrm{v})$ containing $5 \mathrm{~g} \quad \mathrm{AgSO}_{4} \quad \mathrm{dm}^{3}$, and $25 \mathrm{ml} \quad 0.05$ $\mathrm{MK}_{2} \mathrm{Cr}_{2} \mathrm{O}_{7}$. The amount of dichromate used for the oxidation of DOC was estimated either from back titration using $0.025 \mathrm{M}$ ferrous ammonium sulphate.

\section{2- Soil-solution extraction and chemical speciation}

The soil solution of all observed soils wasobtained by vacuum displacement method (Wolt and Graveel, 1986), air dried soil samples (100 g each) werewetted with redistilled water to $100 \%$ field water capacityand then incubated at room temperature for 72 hours and the soil solution was obtained with theuse of a vacuum pump and filtered for the following analysis :

The concentration of major cations ; $\mathrm{Na}, \mathrm{K}, \mathrm{Ca}, \mathrm{Mg}$ and major anions $\left(\mathrm{CO}_{3}, \mathrm{HCO}_{3}, \mathrm{Cl}, \mathrm{SO}_{4}\right)$ were determined according to (page et.al.,1982). The concentration of (Co, $\mathrm{Cu}, \mathrm{Cd}, \mathrm{Fe}, \mathrm{Mn}, \mathrm{Ni}, \mathrm{Pb}, \mathrm{Si}, \mathrm{PO}_{4}$ and $\mathrm{Zn}$ ) were determined by Inductively Coupled Plasma (ICP) Model Ultima-

\section{2-Data treatment:}

Speciation calculations were performed using MINTEQA2 ver3.11 (Allison et al., 1991). The calculated data are listed in Table ( 1 ).
3-Constructing stability diagrams:

Stability diagrams were constructed according to Sposito (1989) and Lindsay (1979).

\section{RESULTS AND DISCUSSION}

Soil General properties :

The data presented in Table 1 show thatsand fraction is prevailed over the other two fractions. It fluctuates between $58.1 \%$ in sludge- soil sample to $82.1 \%$ in the virgin soil sample. On the other hand, the data shows that the clay content is higher in sludge - soil $(23.4 \%)$ compared with virgin soil sample $(2.70 \%)$. That is may due to sedimentation of fine particles exist in sludge, beside to the influence of organic acids released from sludge's decomposition upon soil particles size.

Table 1. Some of physical and chemical properties of the tested soils

\begin{tabular}{lcc}
\hline Items & $\begin{array}{c}\text { Control soil } \\
\text { ( virgin ) }\end{array}$ & $\begin{array}{c}\text { Sludge- soil } \\
\text { (cultivated) }\end{array}$ \\
\hline Particle size distribution(\%) & 82.10 & 58.10 \\
Sand & 15.20 & 18.50 \\
Silt & 2.70 & 23.40 \\
Clay & Loamy Sand & Sandy Clay Loam \\
Texture class & 1.54 & 1.09 \\
Total calcium carbonate \% & 7.45 & 7.01 \\
Soil pH (paste) & 0.82 & 1.41 \\
Soil ECe (dSm-1) & 0.19 & 5.35 \\
Soil organic matter (\%) & 0.19 \\
\hline
\end{tabular}

Table (1) refers that the continuous application of sewage effluent markedly reduced both soil $\mathrm{pH}$ as well as $\mathrm{CaCO}_{3}$ content .These findings were probably as a result of organic acids and $\mathrm{CO}_{2}$ produced during sludge decomposition. Alternatively, electrical conductivity (EC) in sludge soil increased. That iscertainly due to salts contained in the applied sludge.

Total metal concentrations in soil solutions are listed in Table (2). It's obvious from the data that concentrations of all tested metals have increased dramatically as a result of sludge amending, particularly, for $\mathrm{Cd}$ which increased by 40 times, while $\mathrm{Pb}$ increased 3 times and $\mathrm{Ni}$ only twice, compared to that concentrations in the virgin soil solution.

Table 2. Chemical Composition of the tested soils calculated as $\mathbf{p} \underline{M}^{*}$

\begin{tabular}{lcc}
\hline Item & Virgin soil & Sludge- amended soil \\
\hline $\mathrm{pH}$ & 7.54 & 6.91 \\
Ionic Strength & $7.35 \mathrm{e}-03$ & 0.0207 \\
Cations & & \\
$\mathrm{Na}$ & 2.690 & 2.6516 \\
$\mathrm{~K}$ & 3.509 & 3.154 \\
$\mathrm{Ca}$ & 3.0300 & 2.602 \\
$\mathrm{Mg}$ & 3.119 & 2.677 \\
\hline $\mathrm{Cd}$ & Trace metals \\
$\mathrm{Co}$ & 7.448 & 5.846 \\
$\mathrm{Cu}$ & 7.355 & 5.022 \\
$\mathrm{Fe}$ & 5.884 & 4.618 \\
$\mathrm{Mn}$ & 6.048 & 4.713 \\
$\mathrm{Ni}$ & 5.563 & 4.475 \\
$\mathrm{~Pb}$ & 5.849 & 5.564 \\
$\mathrm{Zn}$ & 6.413 & 5.885 \\
$\mathrm{CO}$ & 5.545 & 4.5036 \\
$\mathrm{Cl}$ & Anions & \\
$\mathrm{Si}(\mathrm{H} 4 \mathrm{SiO} 4)$ & 3.0246 & 2.3979 \\
$\mathrm{SO} 4$ & 2.720 & 2.5228 \\
$\mathrm{NO} 3$ & 2.6688 & 2.6307 \\
$\mathrm{PO4}$ & 3.0135 & \\
$\mathrm{DOC}$ & ------ & 2.5528 \\
\hline p $\boldsymbol{M}=-\log \boldsymbol{M}^{-1}$ & & 2.331 \\
& &
\end{tabular}


Speciation of the tested metals:

The Speciation of the tested metals were performed using the MINEQL+4.6 program (Schecherand McAvoy, 2003). Table 2 represents the input data of the various ions; calculated as pM ( minus log of molar concentration ).
The proportions of various species of the tested metals represent as per cent of their corresponding totals, as well as, their activities $\left(\mathrm{Ml}^{-1}\right)$ are listed in Table 3.

Table 3. Speciation (\%) and activities $\left(\mathrm{MI}^{-1}\right)$ of the tested metals.

\begin{tabular}{|c|c|c|c|c|c|}
\hline \multicolumn{3}{|c|}{ Virgin soil } & \multicolumn{3}{|c|}{ sludge- soil } \\
\hline Species & $\%$ of total & Activity $\left(\mathrm{MI}^{-1}\right)$ & Species & $\%$ of total & Activity $\left(\mathrm{MI}^{\mathrm{I}}\right)$ \\
\hline \multicolumn{6}{|c|}{ Cd species } \\
\hline $\mathrm{Cd}^{+2}$ & 79.03 & $1.96 \mathrm{E}-08$ & $\mathrm{Cd}^{+2}$ & 19.89 & $1.61 \mathrm{E}-07$ \\
\hline $\mathrm{CdCl}+$ & 9.97 & 3.24E-09 & $\mathrm{CdCl}+$ & 3.21 & $3.97 \mathrm{E}-08$ \\
\hline $\mathrm{CdSO}_{4} \mathrm{aq}$ & 7.46 & $2.66 \mathrm{E}-09$ & $\mathrm{CdSO}_{4} \mathrm{aq}$ & 3.69 & $5.29 \mathrm{E}-08$ \\
\hline $\mathrm{CdCO}_{3}$ & 1.67 & $5.97 \mathrm{E}-10$ & $\mathrm{CdCO}_{3}$ & 0.36 & $5.17 \mathrm{E}-09$ \\
\hline $\mathrm{CdHCO} 3+$ & 1.53 & 4.97E-10 & CdHCO3+ & 1.18 & $1.46 \mathrm{E}-08$ \\
\hline $\mathrm{CuHPO}_{4}$ & ------ & ---------- & $\mathrm{CdHPO}_{4}$ & 58.72 & $8.4 \mathrm{E}-07$ \\
\hline Cd DOM & ----- & ------ & Cd DOM & 12.67 & $1.65 \mathrm{E}-07$ \\
\hline \multicolumn{6}{|c|}{ Ni species } \\
\hline $\mathrm{Ni}^{+2}$ & 83.8 & $8.26 \mathrm{E}-07$ & $\mathrm{Ni}^{+2}$ & 38.56 & $5.96 \mathrm{E}-07$ \\
\hline $\mathrm{NiSO}_{4} \mathrm{aq}$ & 6.73 & $9.54 \mathrm{E}-08$ & $\mathrm{NiSO}_{4} \mathrm{aq}$ & 6.09 & $1.67 \mathrm{E}-07$ \\
\hline $\mathrm{NiHCO}_{3}^{+}$ & 6.31 & $8.15 \mathrm{E}-08$ & $\mathrm{NiHCO}_{3}^{+}$ & 8.89 & $2.1 \mathrm{E}-07$ \\
\hline $\mathrm{NiCO}_{3} \mathrm{aq}$ & 2.82 & $3.99 \mathrm{E}-08$ & $\mathrm{NiCO}_{3} \mathrm{aq}$ & 1.11 & $3.04 \mathrm{E}-08$ \\
\hline NiHPO4(aq) & ----- & ------ & $\mathrm{NiHPO} 4(\mathrm{aq})$ & 20.23 & $5.54 \mathrm{E}-07$ \\
\hline Ni DOM & ----- & ------ & Ni DOM & 24.55 & $6.11 \mathrm{E}-07$ \\
\hline \multicolumn{6}{|c|}{$\mathrm{Pb}$ species } \\
\hline $\mathrm{PbCO}_{3} \mathrm{aq}$ & 55.86 & $2.16 \mathrm{E}-07$ & $\mathrm{~Pb} \mathrm{CO}_{3} \mathrm{aq}$ & 4.59 & $6.02 \mathrm{E}-08$ \\
\hline $\mathrm{Pb}^{+2}$ & 18.21 & $4.90 \mathrm{E}-08$ & $\mathrm{~Pb}^{+2}$ & 1.75 & $1.29 \mathrm{E}-08$ \\
\hline $\mathrm{Pb} \mathrm{OH}^{+}$ & 12.18 & 4.29E-08 & $\mathrm{Pb} \mathrm{OH}^{+}$ & 0.29 & 3.34E-09 \\
\hline $\mathrm{Pb} \mathrm{HCO}_{3}^{+}$ & 8.85 & $3.12 \mathrm{E}-08$ & $\mathrm{~Pb} \mathrm{HCO}_{3}^{+}$ & 2.6 & $2.95 \mathrm{E}-08$ \\
\hline $\mathrm{Pb} \mathrm{SO}_{4} \mathrm{aq}$ & 3.59 & 1.39E-08 & $\mathrm{Pb} \mathrm{SO}_{4} \mathrm{aq}$ & 0.68 & 8.9E-09 \\
\hline $\mathrm{Pb} \mathrm{HPO}_{4}$ & ---- & ----- & $\mathrm{Pb} \mathrm{HPO}_{4} \mathrm{aq}$ & 1.28 & $1.68 \mathrm{E}-08$ \\
\hline $\mathrm{Pb} \mathrm{DOM}$ & ----- & --------- & $\mathrm{Pb} \mathrm{DOM}$ & 88.54 & $1.05 \mathrm{E}-06$ \\
\hline
\end{tabular}

In virgin soil sample, On mean basis, the data show that the tested metals exist mainly in soil solution as free ions $\mathrm{M}^{2+}(60.35 \%)$, followed in decreasing order by carbonate species $\mathrm{MCO}_{3}$ aq $(20.12 \%)$. Mean while, MSO4 aq, $\mathrm{MHCO}_{3}^{+}$, and $\mathrm{MOH}^{+}$species were nearly equal (flocculated around $5 \%$ ) of their total species, and $\mathrm{MCl}^{+}$ only amounted $(2.76 \%)$.

Furthermore, the data of virgin soil show that the free ion $\left(\mathrm{M}^{2+}\right)$ was the dominate species for $\mathrm{Ni}(83.8 \%)$ and Cd (79.03\%). Mean while, the most prominent species of pb was $\mathrm{PbCO} 3$ (aq), which accounts more than $55 \%$ of total $\mathrm{Pb}$ species.

Also, the present results showed that $\mathrm{Cd}$ prefers to complex with $\mathrm{Cl}^{+}$ligand (9.97\%) more than that in $\mathrm{SO} 4$ ligand $(7.46 \%)$. Mean while the other possible complex ionscould be ignored. This results may confirmed by results of Garcia- Miragaya and Page (1976) who mentioned that $\mathrm{Cd}$ could make staple complexes with chloride ligands.

In virgin soil, the Table showed that the second most abundant form of $\mathrm{Ni}$ was $\mathrm{NiSO}_{4}$ aq and $\mathrm{NiHCO}_{3}{ }^{+}$ (around 6\% for each), followed by $\mathrm{NiCO}_{3}$ (aq), which exhibits minor part $(2.82 \%)$.

Meanwhile $\mathrm{Pb}$ speciation show that the second order species was $\mathrm{Pb}^{+}(18.21 \%)$, followed by $\mathrm{PbOH}^{+}$ $(12.48 \%), \mathrm{Pb}\left(\mathrm{HCO}_{3}\right)^{+}(8.85 \%)$, and $\mathrm{PbSO}_{4}$ aq $((3.59 \%)$, (Table 3).

In sewage - amended soil solution, Table (3) indicates that organic complexing exist at appreciable amounts. On mean basis, this speciesaccounted (41.92\%), followed by $\mathrm{MHPO}_{4}$ species $(26.74 \%)$, and $\mathrm{M}^{2+}$ species (20.07\%). Mean while $\mathrm{MHCO}_{3}{ }^{+}, \mathrm{MSO}_{4}$ (aq) and $\mathrm{MCO}_{3}$ (aq) species contribute $4.22 \%, 3.49 \%$, and $2.02 \%$, respectively), while the other possible species could be neglected. It is clear from results that the mean value of uncomplexed species $\left(\mathrm{M}^{+2}\right)$ decreased from $60.35 \%$ (in virgin soil) to $20.07 \%$ (in sludge-soil).

The influence of organic amending on metal speciation, was also studied by USMAN et al,(2005) and Beata et al. (2014). They concluded that the free portion of metal decreased as amending rate increased. Moreover, Mateusz et al (2017) examined the changes in concentrations and speciation of $\mathrm{Cu}, \mathrm{Zn}$, and $\mathrm{Pb}$ in soil solutions acquired from soils contaminated by emissions and treated with organic materials. They indicated that applying acidic lignite resulted in the release of free metal ions into the solution, while the application of immature compost led to the formation of metal complexes with soluble organic compounds.

Cd speciation in sludge - soil solution (Table 3) showed that the primary species for $\mathrm{Cd}$ was $\mathrm{CdHPO} 4 \mathrm{aq}$ (58.72\%), followed by $\mathrm{Cd}^{2+}(19.90 \%)$, andCd-DOC (12.67). In contrast, in $\mathrm{Ni}$ speciation the free portion of $\mathrm{Ni}$ was the prominent species $(38.56 \%)$, followed by Ni-DOC (24.55\%), $\mathrm{NiHPO}_{4}(20.23 \%), \mathrm{NiHCO}_{3}{ }^{+}(8.89 \%)$, and $\mathrm{NiSO}_{4}$ aq $(6.09 \%)$.

$\mathrm{Pb}$ speciation, (Table 3) indicated that organic complexes was the most prominent species (88.54\%), while the contribution of $\mathrm{PbCO}_{3}$ aq was $(4.59 \%)$ andthe other possible species of $\mathrm{Pb}$ could be neglected.

The high association of $\mathrm{pb}$ with organic ligands may be confirmed with results of Ivanaet al., (2016) who found that $\mathrm{Pb}^{+2}$ ions form the most stable complexes with organic ligands. Moreover, they expected that $\mathrm{Pb}$ could competing the other investigated M (11) in binding sites of organic ligands. 
Activities and prediction of Solid phases which controlling solubility of the tested metals:

The influence of sludge application on activities of the tested metals are listed in Table 3).

As shown from Table (3) that the activities (Ml-1) of both $\mathrm{Pb}$ and $\mathrm{Ni}$ decreased by ( $26 \%$ and $72 \%$ ), respectively, compared with their corresponding values in virgin soil. Meanwhile for $\mathrm{Cd}$, the activity was increased around 8 times more than that in virgin soil. These findings suggesting that amending soil with sludge probably inhibit pollution hazards of some heavy metals and visa versa for some others.In the same connections ,He and Singh , 1993b and Shumun, 1998) reported that certain organic soil amendments had the ability to ameliorate heavy metal toxicity to plants.So, the association of a metal and organic colloidsdeserve special attention.

Solubility lines of M-ferrite were developed in equilibrium with $\mathrm{Fe}(\mathrm{OH})_{3}$ (amorphous), $\mathrm{Fe}(\mathrm{OH})_{3}$ (soil$\mathrm{Fe}$ ). Solubility lines of M-aluminate were developed in equilibrium with gypsite, or $\mathrm{Al}(\mathrm{OH})_{3}$ amorphous . Solubility line of M-silicate were developed in equilibrium with $\mathrm{SiO} 2$ (quartz or soil), while for M-phosphate minerals were developed in equilibrium with gypsite and Caphosphate minerals as described by Sposito (1989) and Lindsay (1979) and plotted in Fig 1(a to c).

Plotting the activity values $\left(\mathrm{Cd}^{+2}\right)$ of the tested metals on corresponding stability diagrams (Fig1a). The data show that the solubility of $\mathrm{Cd}$ in virgin soil was closed to the solubility of $\mathrm{CdCO}_{3}(\log \mathrm{CO} 2=-2.52)$ and $\mathrm{CdSO}_{4}$ -
$2 \mathrm{Cd}(\mathrm{OH})_{2}$ at $(\log \mathrm{So} 4=-2)$, while in sludge soil ,the value of $\mathrm{Cd}^{+2}$ was undesaturated with respect the constructed $\mathrm{Cd}-$ minerals. This suggested that other possible solid phase of cadmium may be controlling its activity in that soil .In the same connection, Emmerich et al., (1982) reported that activities of $\mathrm{Cd}, \mathrm{Pb}$, and $\mathrm{Zn}$ in sludge - amended soil were undesaturation with respect the established minerals, suggested that may be another mechanisms involves the solid phase in soil that could control the activity of that metals (as specific adsorption, precipitation, coprecipitation , complexation,...).

Fig $1 \mathrm{~b}$ shows suggested that the activity of $\mathrm{Ni}^{+2}$ in virgin soil is governed by $\mathrm{Ni}_{3}\left(\mathrm{PO}_{4}\right)_{2}$ in equilibrium by gypsite. While in the value of $\mathrm{Ni}^{+2}$ in sludgesoil is controlled by $\mathrm{Ni}_{3}\left(\mathrm{PO}_{4}\right)_{2}$ in equilibrium with $\mathrm{Ca}$ - phosphate mineral at $\left(\log \mathrm{CO}_{2}=-4.52\right)$. Also, Fig (1c) indicated that $\mathrm{Pb}_{3}\left(\mathrm{CO}_{3}\right)_{2}(\mathrm{OH})_{2}$ is the possible solid phase which may be controlled the activity of $\mathrm{Pb}^{+2}$, in both virgin and sludge soil. Similar conclusion was also observed by El-Gendiet al (2017) who mentioned that values of $\mathrm{pb}^{+2}$ values were supersaturated with respect of $\mathrm{pb}(\mathrm{OH})_{2}, \mathrm{pbCO}_{3}$ and $\mathrm{pb}_{3}\left(\mathrm{CO}_{3}\right)_{2}(\mathrm{OH})_{2}$ at 0.0003 atm. $\mathrm{CO}_{2}$. Mean while, In auto exhausted soil, El-Gendi(1994) reported that that the $\mathrm{pb}^{2+}$ activities were within the range maintained by the formation and /or mixture of $\mathrm{PbCO}_{3}, \quad \mathrm{pb}_{4} \mathrm{O}\left(\mathrm{PO}_{4}\right)_{2}$, $\mathrm{pb}_{5}\left(\mathrm{PO}_{4}\right)_{3} \mathrm{OH}, \mathrm{pb}_{3}\left(\mathrm{PO}_{4}\right)_{2}$ at equilibrium with (hydroxy apatite ) and $\mathrm{CaCO}_{3}$ at 0.003 atm. $\mathrm{CO}_{2}$., and $\mathrm{pbHPO}_{4}$ at equilibrium with ( tricalcium phosphate) and $\mathrm{CaCO}_{3}$ at 0.003 atm. $\mathrm{CO}_{2}$.

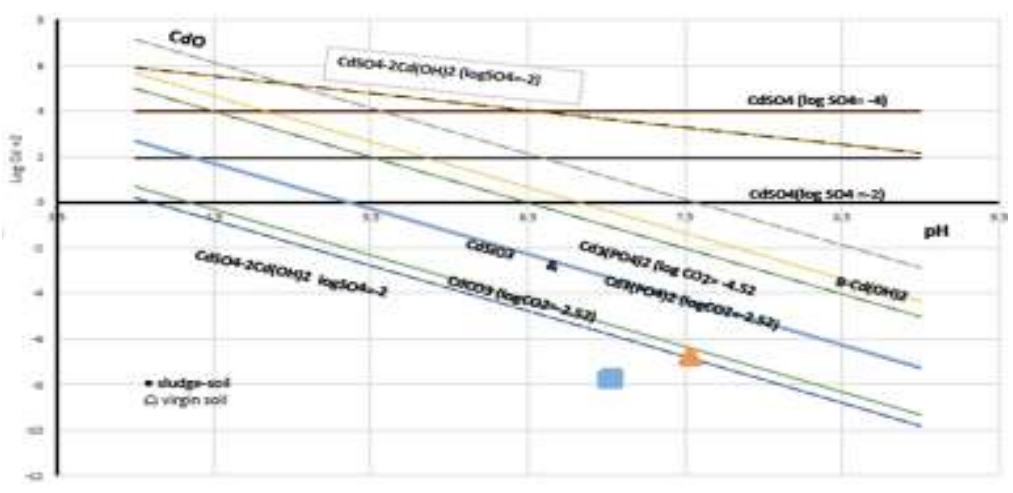

Fig (1a): Stability diagrams of Cd minerals .

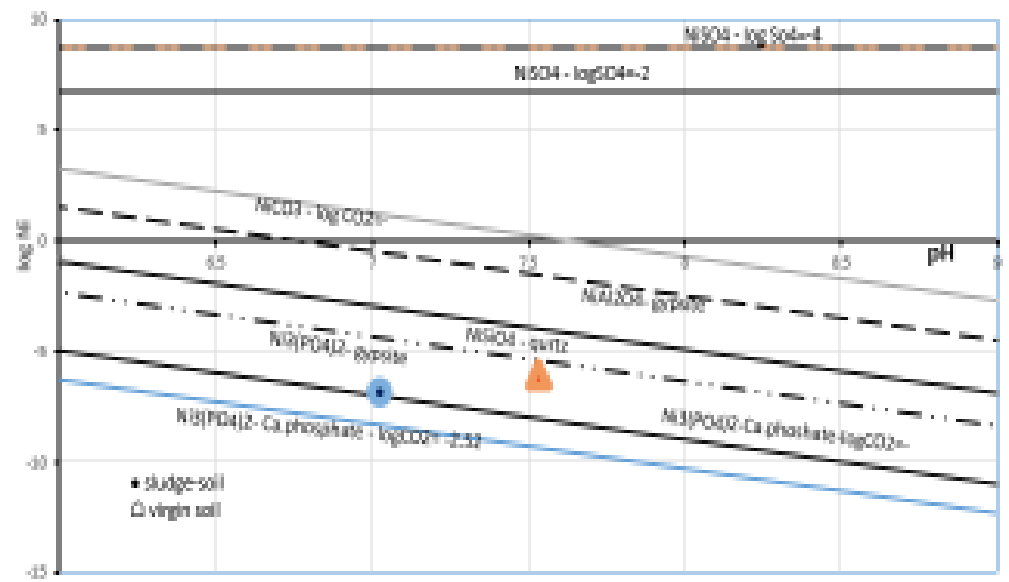

Fig (1b): Stability diagrams of Ni minerals 


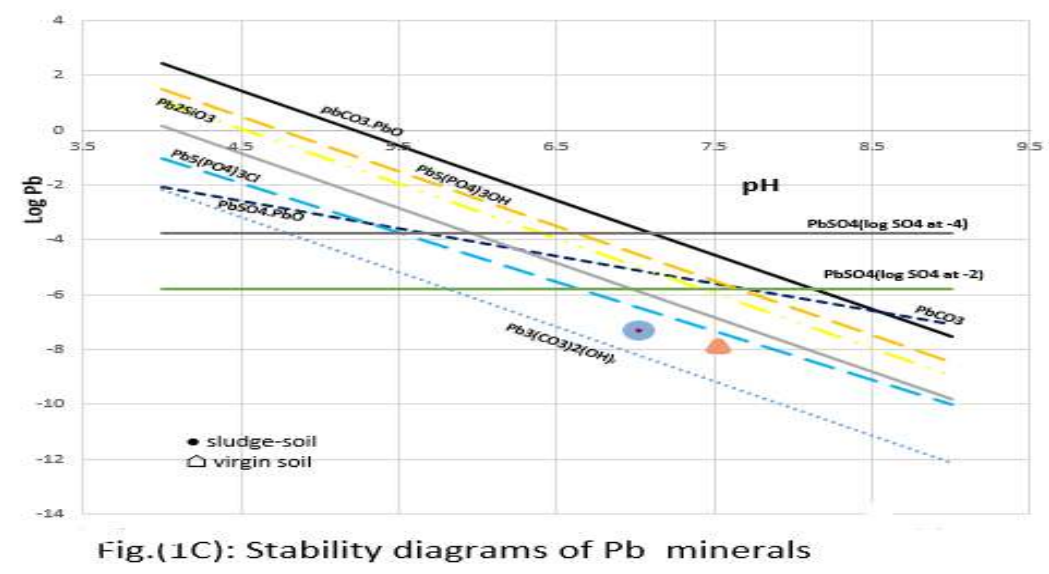

\section{REFERENCES}

Allison, J. D., Brown, D. S. and Novo-Gradac, K. J. (1991). MINTEQA2/ PRODEFA2, a geochemical assessment model for environmental systems: Version 3.0 User's manual; U.S. EPA: Athens, GA.

Alloway, B. J. (1995). Heavy Metals in Soils. Blackie Academic and Professional, Glasgow, Scotland, $368 \mathrm{pp}$.

Apte, S. C. and Batley, G. E. (1995). Trace metal speciation of labile chemical species in natural waters and sediments: nonelectrochemical approaches. Metal Speciation and Bioavailability in Aquatic Systems (Tessier, A. and Turner, D. R., eds.), 256-306, John Wiley \& Sons, Chichester

Artiola, J.F. (2005). Speciation of copper. In: Handbook of elemental speciation II. Species in the environment, food, medicine and occupational health. CORNELIS R. CARUSO J., CREWSH., HEUMANN K. (eds). John Wiley\&Sons Ltd., England, 174-187.

Beata, R., Wiesław S. and Jan Ł. (2014). Zinc speciation in soil solution of selected Poland's agricultural soils. Zemdirbyste-Agriculture. 101(2): 147-152.

Cances, B., Ponthieu, M., Castrec-Pouelle, M., Aubry, E., Benedetti, M.F. (2003). Metal ions speciation in a soil and its soil solution:experimental data and model results. Geoderma, 113: 341-355.

Chapman, H.D. and Pratt, P.F. (1978). Methods of analysis for soils, plants and waters. pp. 50 Univ. of California Div. Agric. Sci., priced publication 4034.

Davis, A., Ruby, M. V. and Bergstom, P. D. (1992). Bio availability of arsenic and lead in soils from the Butte, Montana, minting district. Environ. Sci. Technol. 26, 461- 468 .

El-Falaky, A.A., Aboulroos, S.A., Lindsay, L.W. (1991). Measurement of cadmium activities in slightly acidic to alkaline soils. Soil Sci.Soc.Am.J.(55)974979.

El-Gendi, S.A., Hassan, M.A. and Elnaka, E.A.(2017). Estimating lead activities in Egyptian alluvial soil using competitive chelation method.Zagazig J.Agric.Res.44(4):1315-1323.
El-Gendi, S.A. (1994). Chemical equilibrium of some heavy metals. Ph.D. thesis. Fac. of Agric., Cairo Univ., Egypt.

Emmerich, W.E., Lund, L.J., Page, A.L. and Chang, A.C. (1982). Predicted solution phase forms of heavy metals in sewage sludge - treated soils. J.Environ . Qual., 11(2): 182 - 186.

Florence, T. M. (1986). Electrochemical approaches to trace element speciation in waters: a review. Analyst 111, 489-505.

Fotovat, A. and Naidu, R. (1997). Ion exchange resin and MINTEQA2 speciation of $\mathrm{Zn}$ and $\mathrm{Cu}$ in alkaline sodic and acidic soil extracts. Australian J. Soil Res. 35, 711-726.

Garcia-Miragaya, J. and Page, A.L. 1976. Influence of ionic strength and inorganic complex formation on the sorption of trace amounts of $\mathrm{Cd}$ by montmorillonite. Soil Sci. Soc. Am. J. 40, 658-663.

He, Q.B. and Singh, R.B. (1993)b. Plant availability of cadmium in soil. II. Factors related to extractability and plant uptake of cadmium in cultivated soils. Acta.Agric.Scan. 43: 143-150.

Ivana, K., Tatjana A., Darko, A.; Ruzica, N., Aleksandar, B., Tatjana, C. and Goran, N. (2016). Interaction of cobalt (II), nickel (II) and zinc (II) with humic-like ligands studied by the ESI-MS and ion-exchange methods. J. Serb. Chem. Soc. 81 (3) 255-270.J. Elem. s. 695-703.

Jackson, J. F. C., Nevissi, A. E. and Dervalle, F. B. (1984). "Soil Chemical Analysis ". Prentice Hall Inc. Engle Works Cliffs. New Jersey.

Katbata-Pendias, A. (1993). Behavioural properties of trace metals in soils. Appl. Geochem. 2, 3-9.

Li Yi, Y. H., Duojun, W. and Yongxuan, Z. (2007). Determination of free heavy metal ion concentrations in soils around a cadmium rich zinc deposit. Geochemical Journal, Vol. 41, pp. 235 240.

Lindsay, W. L. (1979). Chemical equilibria in soils. John Wiley and Sons. New York.

Mateusz, C., Anna, K. and Bernard, G. (2017). Speciation of $\mathrm{Cu}, \mathrm{Zn}$, and $\mathrm{Pb}$ in Soil Solutions Extracted from Strongly Polluted Soils Treated with Organic Materials.Pol. J. Environ. Stud .26(2): 567-575. 
Meeussen, J. C. L. (2003). ORCHESTRA: An objectoriented framework for implementing chemical equlibrium models. Environ. Sci.Technol. 37, 1175-1182.

Moore, T.R. (1985) The spectrophotometric determination of dissolved organic carbon in peat waters. Soil SciSoc Am J 49:1590-1592

Mota, A. M. and Correia dos Santos, M. M. (1995). Trace metal speciation of labile chemical species in natural waters: electrochemical methods. Metal Speciation and Bio availability in Aquatic Systems (Tessier, A. and Turner, D. R., eds.), 205-258, John Wiley \& Sons, Chichester.

Nordstrom, D. K. (1996). Trace metal speciation in natural waters: computational vs. analytical. Water Air Soil Pollut. 90,257-267.

Norvell, W. A. and Lindsay, W. L. (1969). Reactions of EDTA complexes of $\mathrm{Fe}, \mathrm{Zn}, \mathrm{Mn}$, and $\mathrm{Cu}$ with soil. Soil ScienceSociety of America Proceedings 33, 86-91.

Norvell, W. A. and Lindsay, W. L. (1972). Reactions of DTPA complexes of iron, zinc, copper, and manganese with soil.Soil Science Society of America Proceedings 36, 773-788.

Page, A. L., Miller, R. H. and Keeney, D.R. (1982)." Methods of soil analysis". Part 2. Chemical and microbiological properties. 2nd ed. Agronomy Series 9, ASA, SSSA, Madison, Wis.

Parker, D. R. and Pedler, J. F. (1996). Reevaluation of the freeion activity model of trace metal availability to higher plants. Plant and Soil 196, 223-228.

Piper, C. S., (1950). "Soil and Plant Analysis", Interscience Publishing Inc. New York.

Schecher, W. D., McAvoy, D. C. (2003): MINEQL+.[4.6]. Environmental Research Software, Hallwell, ME, USA.

Shumun, M.L. (1998). Effect of organic waste amendments on cadmium and lead in soil fraction of two soils. Commun.SoilSci.PlantAnal.29 (20): 2939-2952.
Sposito, G. and Mattigod, S.V. (1980). Geochem: a computer program for the calculation of chemical equilibria in soil solution and other natural water systems. Kearney Found. Soil Sci, Univ of California, Riverside.

Sposito, G. (1989). The chemistry of soils. Oxford University Press. New York.

Temminghoff, E. J. M., Plette, A. C. C., Van Eck, R. and Van Riemsdijk, W. H. (2000). Determination of the chemical speciation of trace metals in aqueous systems by WageningenDonnan Membrane Technique. Anal. Chim. Acta417, 149-157.

Thomas, J., Tjisse, H., Jos, P. and Sjoerde, A. (2005). Modeling of the solid-Solution Partitioning of Heavy Metals and Arsenic in Embanked Flood Plain Soils of the Rivers Rhine and Meuse. Environ. Sci. Technol. 39, 7176-7184.

Ure, A.M. and Davidson, C.M. (2002). "Chemical Speciation in the Environment", Second Edition. Blackwell Science Ltd.

Usman, A.R.A., Kuzyakov, Y. and Stahr, K. (2005). Effect of Immobilizing Substances and Salinity on Heavy Metals Availability to Wheat Grown on Sewage Sludge-Contaminated Soil. Soil \& Sediment Contamination, 14:329-344.

Weng, L., Temminghoff, E. J. M. and Van Riemsdijk, W. H. (2001). Contribution of individual sorbents to the control of heavy metal activity in sandy soil. Environ. Sci. Technol. 35, 4436-4443.

Wolt, J. D. and Graveel, J. 1986. A rapid routine method for obtaining soil solution using vacuum displacement. Soil Science Society of America Journal, 50: 602-605.

Workman, S. M. and Lindsay, W. L. (1990). Estimating divalent cadmium activities measured in arid-zone soils using competitive chelation. Soil Sci. Soc. Am. J. 54, 987-993.

Yuan, G. (2009). Copper, zinc and nickel in soil solution affected by biosolids amendment and soil management. Aust. J. Soil Res., 47: 305-310

Zsolnay, A., 2003. Dissolved organic matter: artefacts, definitions and functions. Geoderma 113, 187-209.

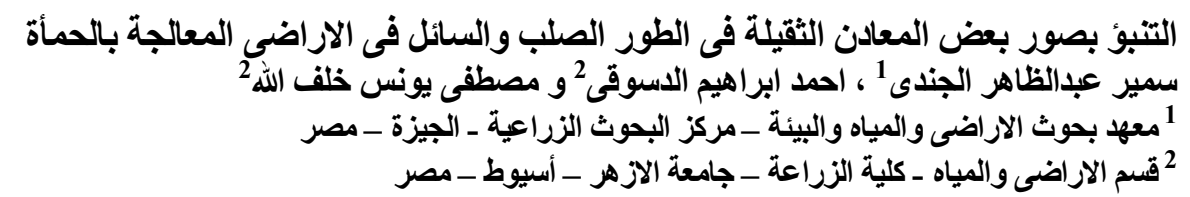

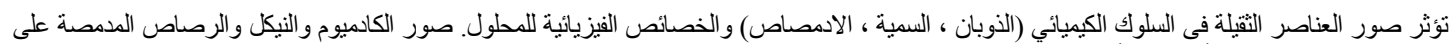

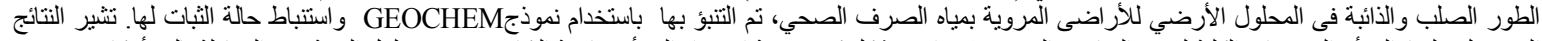

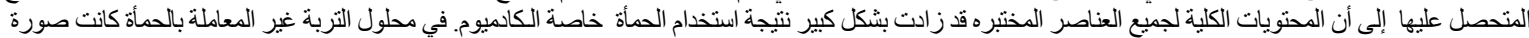

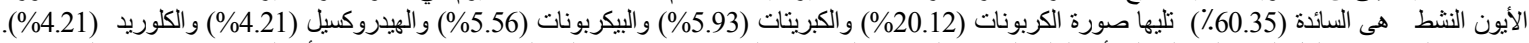

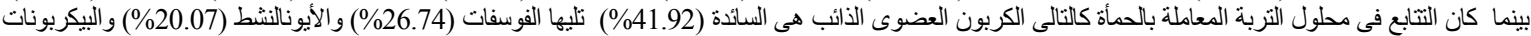

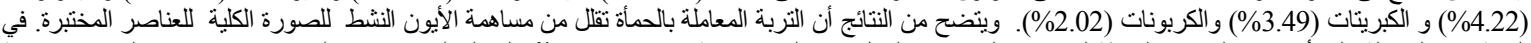

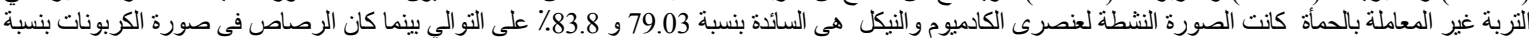

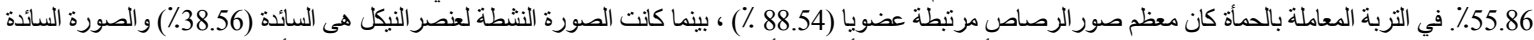

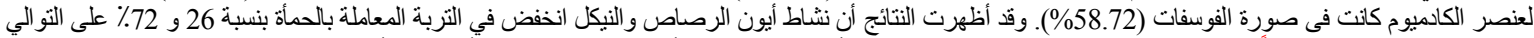

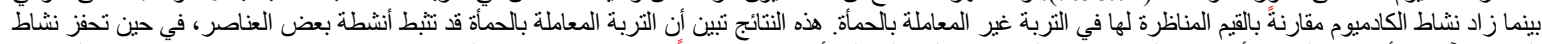

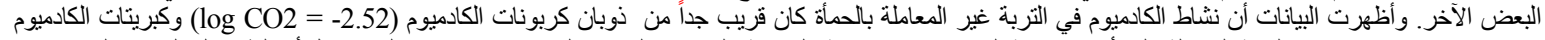

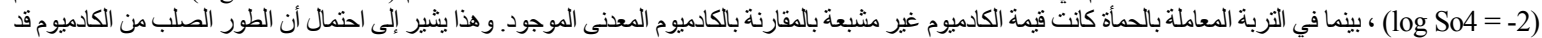

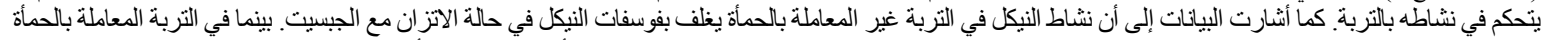

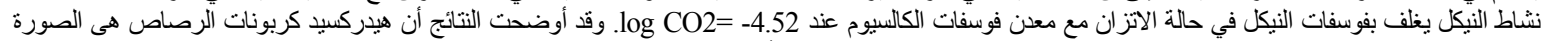

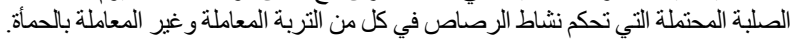

